Activin-like kinase receptors 17

Adenovirus 95

Alkaline phosphatase 109

Amelogenesis imperfecta 7

Amelogenin 7

Biomineralization 7

Bone morphogenetic protein(s) 28, 109

C2C12 cells 28

Cell fusion 67

Chondrocyte 41

Chondrogenesis 79

Chondroinduction 41

Colla1-GFP 120

Collagen tube 153

Degradation rate 153

Demineralized bone powder 41

Dura mater 54

Extracellular matrix 87

Fibroblast growth factors 54

Fracture healing 95

Gene expression 41

Green fluorescent protein 120

Hypoxia-inducible factor-1 $\alpha 87$

Interleukin-4, cell fusion 67

Keloids 87

Keratinocyte 134
Macrophage, cell fusion 67

Marrow stromal cells 109

Mesenchymal stem cells 109

Microarray 28

Myotube 67

\section{NFATC2 67}

Odontogenesis 7, 120

Oral mucosa, tissue engineered 134

Osteoblast 95

- differentiation 28

Osteogenesis 109, 120

Peripheral nerve 153

Perlecan 79

Progenitor cells 120

Prostaglandin $\mathrm{F}_{2 \alpha} 67$

Regeneration 153

Replacement teeth 17

Representational difference analysis 41 Runx2/Cbfa 28

Stem cells 120

Sutures 54

TGF- $\beta$ family member signaling 17

Tissue engineering 134

- fibrosis 87

- interactions 54

Transcription factors 109

Transgenics 7

Vascular endothelial growth factor 87 